\title{
THE EFFECT OF BANK'S INTERNAL FACTORS TOWARDS MICRO FINANCING IN ISLAMIC COMMERCIAL BANK AT INDONESIA
}

\author{
Ulfa Rizki Utami \\ Faculty of Islamic Studies, Universitas Muhammadiyah \\ Surakarta \\ email: rizkiulfa22@gmail.com
}

\section{ABSTRACT}

The main driver of Indonesian economic wheel is the small and medium-sized enterprises (SME). This SME plays significant role as well in providing employment opportunity while in the same time adding numbers of business units that support the household income from the business. One of the obstacles faced by SME is the capital and financing constraint, especially for the financing from the bank. Without financing, SME will lose its capability to grow and develop since the main support for SME is the capital and financing itself. This research aims to know the internal factors affecting the third party fund, inflation and the rate of return in the period of 2012-2014 in Islamic commercial banks at Indonesia. The research will carry out the OLS procedure since this technique allows us to know clearly the factors affecting financing in the SME. Our research shows that third party fund significantly affect SME financing with positive sign. Meanwhile, the rate of return is observed to affect negatively to the financing. Inflation also has significant and positive effect with bigger coefficient compared to others in financing for SME.

Keywords: SME, third party fund, inflation, rate of return, OLS. 


\section{INTRODUCTION}

The free market environment which will be faced by Indonesia gives impact on the society to shift their current job towards entrepreneurship. This entrepreneurship could come in many forms, but most of those businesses are small and mediumsized enterprise (SME). In general, SME provides better life. However, capital constraint is the main barrier for people to establish their own business.

In Indonesia, one of distinguished character from SME can be observed during the economic crisis shock on 1997-1998 which wipes out almost entire economic sector at that time. Back at that crisis, SME was able to survive facing the shock compared to other big companies. This SME plays significant role as well in providing employment opportunity while in the same time adding numbers of business units that support the household income from the business. SME also has flexibility compared to other big companies.

The growth and development is therefore held as important as SME has important role in boosting economic condition in a country, including Indonesia. As an illustration, SME contributes to Indonesia by providing employment absorption up to $99.74 \%$ out of total national absorption. In addition to that, SME's contribution for GDP counts for 547 billion Rupiah, or equal to $56,73 \%$ of GDP. Such contribution proves that SME has very strong ability to boost up and enhance national economic condition (Prawirokusumo, 2001).

According to SME's development statistic from 2012 until 2014 which is shown at table 1, SME in Indonesia experience growth for more or less about 1.4 million yearly. 
Table 1. The growth of SME 2012-2014

\begin{tabular}{|c|c|c|c|c|c|}
\hline No & Indicator & Unit & 2012 & 2014 & $\begin{array}{c}\text { Growth } \\
\text { 2012-2014 }\end{array}$ \\
\hline 1 & Number of SME & million & 56.5 & 57.9 & 1.4 \\
\hline 2 & Employment & million & 110 & 118 & 8 \\
\hline 3 & GDP contribution & $\begin{array}{l}\text { billion } \\
\text { Rupiah }\end{array}$ & 4.869 & & \\
\hline
\end{tabular}

Source: Ministry of Co-operation and SME Indonesia

The data above shows that SME in Indonesia witnesses continuous growing from 2012-2014. This growth is also expected to continue until next following years. This growth is also accompanied with problem faced by SME which according to Winarni (2006), the problem is the insufficient capital.

In the same time, Islamic bank also experiences significant growth from year to year, whether from the financing or deposit side. The financing channeled to SME is also linked tightly to the availability of fund collected by Islamic banks from third party.

The macro variable whether it is inflation of rate of return is the important component that has to be highlighted after the third party fund amount. The rate of return also influences SME since the higher the rate of return for financing, the more it causes reluctance from society which is the SME to use Islamic bank's profit sharing service when the cost is not equal to profit to be gained by SME. In addition, inflation also affects bank's decision in channeling the fund.

With the variables which have effect on fund allocation on micro financing as mentioned above, this study will focus on the effect of third party fund, inflation and the rate of return towards the total amount channeled for financing SME in Islamic 
commercial bank. The study also will focus on the period of 2012 until 2014. The factors behind the decision which influence financing towards small and medium-sized enterprises from Islamic commercial bank are worth to be investigated. This is in addition whether term and condition of financing also counts as priority for the SME to undertake any other party financing on its business.

In order to make comprehensive research, this paper will start with the literature review. Subsequent to the literature review, some theoretical foundation will be discussed. Afterwards, we will explain the research methodology carried out in this paper for investigating the problem. The result of the research comes next along with the discussion of the result. Many statistical examinations are also arranged within it. Finally, we provide conclusion of the research by acknowledging the limitation of the research as well as providing some suggestions on the topic.

\section{LITERATURE REVIEW}

There have been some researches which focus on the same topic of our interest. We will sum up those previous researches in a table model to understand its substance in a quick way. There are 10 researches that we will show here which started from 2014 up to 2016 to make sure that we obtain the latest research as new as possible. The result is showed in the following table. 
Table 2. Compilation of Literature Review

\begin{tabular}{|c|c|c|c|c|}
\hline No. & $\begin{array}{c}\text { Author and } \\
\text { Journal }\end{array}$ & Title & Variables & Results \\
\hline 1 & $\begin{array}{l}\text { Sri Delasmi } \\
\text { Jayanti. } \\
\text { I-Economi } \\
\text { Vol.2.No.2 } \\
(2016)\end{array}$ & $\begin{array}{l}\text { The Effect of } \\
\text { Inflation and BI } \\
\text { Rate on SME } \\
\text { financing (A case } \\
\text { study on Islamic } \\
\text { Commercial } \\
\text { Bank). }\end{array}$ & $\begin{array}{l}\text { Inflation, BI rate, } \\
\text { SME financing }\end{array}$ & $\begin{array}{l}\text { The result shows that both } \\
\text { inflation and BI rate affects } \\
\text { significantly towards SME } \\
\text { financing. }\end{array}$ \\
\hline 2 & $\begin{array}{l}\text { Oki Irawan. } \\
\text { Jurnal } \\
\text { Liquidity } \\
\text { Vol.5,No.2 } \\
(2016): 127- \\
133\end{array}$ & $\begin{array}{l}\text { Third Party Fund, } \\
\text { Capital Adequacy } \\
\text { Ratio (CAR), } \\
\text { Non-Performing } \\
\text { Financing and } \\
\text { the Rate of return } \\
\text { on investment of } \\
\text { SME financing. }\end{array}$ & $\begin{array}{l}\text { Third Party Fund, } \\
\text { Capital Adequacy } \\
\text { Ratio (CAR), } \\
\text { Non-Performing } \\
\text { Financing, Rate } \\
\text { of return on } \\
\text { investment of } \\
\text { SME financing, } \\
\text { amount allocated } \\
\text { for SME } \\
\text { financing. }\end{array}$ & $\begin{array}{l}\text { The result of t-test shows } \\
\text { that third party fund has } \\
\text { significant effect on total } \\
\text { fund allocated towards SME. } \\
\text { Meanwhile, the F-statistic } \\
\text { shows that all variables which } \\
\text { are third party fund, capital } \\
\text { adequacy ratio (CAR), non- } \\
\text { performing financing, rate } \\
\text { of return are significant. The } \\
\text { R-square which is close to } \\
\text { the value of } 1 \text { shows that the } \\
\text { regression can explain much } \\
\text { of the problem observed. }\end{array}$ \\
\hline 3 & $\begin{array}{l}\text { Raden Yogi } \\
\text { Arieffiandi. } \\
\text { Journal.ipb. } \\
\text { ac.id E-ISSN: } \\
2460-7819 \\
(2016) \\
\text { Vol.2,No } 3 .\end{array}$ & $\begin{array}{l}\text { Factors } \\
\text { Influencing Rate } \\
\text { of Collectible } \\
\text { Financing Fund } \\
\text { on SME Sector } \\
\text { (A Case Study on } \\
\text { Certain Islamic } \\
\text { Bank at West } \\
\text { Jakarta Branch). }\end{array}$ & $\begin{array}{l}\text { Level of financing } \\
\text { repayment, type } \\
\text { of financing } \\
\text { contract, rate of } \\
\text { return, maturity, } \\
\text { limit ratio of } \\
\text { financing, type } \\
\text { of collateral, } \\
\text { economic sector, } \\
\text { type of business } \\
\text { body, Z-score } \\
\text { ratio }\end{array}$ & $\begin{array}{l}\text { The result shows that } \\
\text { factors which influence the } \\
\text { payment collectability from } \\
\text { the customer of Islamic } \\
\text { commercial bank are type } \\
\text { of financing contract, rate } \\
\text { of return, economic sector, } \\
\text { and the Z-score of that SME. } \\
\text { The analysis on internal } \\
\text { and external environment } \\
\text { comes out with the important } \\
\text { factor which can be used in } \\
\text { reducing the number of NPF } \\
\text { in certain Islamic Bank at } \\
\text { West Jakarta that is by doing } \\
\text { defensive strategy. }\end{array}$ \\
\hline
\end{tabular}




\begin{tabular}{|c|c|c|c|c|}
\hline No. & $\begin{array}{c}\text { Author and } \\
\text { Journal }\end{array}$ & Title & Variables & Results \\
\hline 4 & $\begin{array}{l}\text { Nurhidayah. } \\
\text { Journal } \\
\text { JIBEKA } \\
\text { Volume } 10 \text {, } \\
\text { Nomor } 1 \\
(2016): 42-48\end{array}$ & $\begin{array}{l}\text { Internal and } \\
\text { External Factors } \\
\text { Affecting the } \\
\text { Financing } \\
\text { allocation } \\
\text { on SME (A } \\
\text { Case Study on } \\
\text { Islamic Banks at } \\
\text { Indonesia). }\end{array}$ & $\begin{array}{l}\text { SME financing } \\
\text { at Islamic Banks, } \\
\text { rate of return, } \\
\text { financing to } \\
\text { deposit ratio, } \\
\text { inflation, GDP. }\end{array}$ & $\begin{array}{l}\text { The result shows based on } \\
\text { the statistical evidence, some } \\
\text { variables such as rate of } \\
\text { return, inflation as well as } \\
\text { GDP does not affect SME } \\
\text { financing done by Islamic } \\
\text { banks. Meanwhile, only } \\
\text { financing to deposit ratio } \\
\text { which has significant effect } \\
\text { on the financing allocation } \\
\text { to the SME by the Islamic } \\
\text { banks. }\end{array}$ \\
\hline
\end{tabular}

5 Kara. Ahkam: Vol.XIII,No. 2, Juli 2013

\section{Contribution of}

Islamic Banks

Financing on the

Development and

Growth of SME.
Islamic financing, small-medium sized enterprise (SME)
The results of this study indicate that the development of Islamic banking financing in an effort to develop SMEs in Makassar during 2010-2011 experienced a fluctuating increase. This reflects that the role of Islamic banking financing in improving SMEs in the city of Makassar has not been optimal. 


\begin{tabular}{|c|c|c|c|c|}
\hline No. & $\begin{array}{c}\text { Author and } \\
\text { Journal }\end{array}$ & Title & Variables & Results \\
\hline 6 & $\begin{array}{l}\text { Roikhan } \\
\text { Mochammad } \\
\text { Aziz. } \\
\text { KINERJA } \\
\text { Volume } 21 \\
\text { No.1 (2017) } \\
\text { page } 17-34\end{array}$ & $\begin{array}{l}\text { Development of } \\
\text { Small Medium } \\
\text { Entreprise } \\
\text { With External, } \\
\text { Intrernal, and } \\
\text { Religiosity } \\
\text { Factors in Islamic } \\
\text { Banks }\end{array}$ & $\begin{array}{l}\text { Inflation, Bank } \\
\text { Indonesia Islamic } \\
\text { Certificate (SBIS), } \\
\text { non-performing } \\
\text { financing, third } \\
\text { party fund, } \\
\text { Islamic banks. }\end{array}$ & $\begin{array}{l}\text { The results of regression } \\
\text { analysis finds independent } \\
\text { variables for external, } \\
\text { internal and religiosity such } \\
\text { as inflation, Bank Indonesia } \\
\text { Islamic Certificate (SBIS), } \\
\text { non-perfoming financing } \\
\text { and third party funds have } \\
\text { simultaneous and partial } \\
\text { effect on SME financing in } \\
\text { Islamic Banking in Indonesia. } \\
\text { The most dominant } \\
\text { regression variable in } \\
\text { influencing SME financing in } \\
\text { Syariah Banking is the non- } \\
\text { performing financing (NPF) } \\
\text { variable. }\end{array}$ \\
\hline 7 & $\begin{array}{l}\text { Raras Palupi } \\
\text { Astarini. } \\
\text { International } \\
\text { Journal of } \\
\text { Science and } \\
\text { Research } \\
\text { Volume } 5 \text { Issue } \\
9 \text { (2016) }\end{array}$ & $\begin{array}{l}\text { The Impact of } \\
\text { Internal and } \\
\text { External Factors } \\
\text { on Financing of } \\
\text { Sharia Bank in } \\
\text { Indonesia }\end{array}$ & $\begin{array}{l}\text { Bank Indonesia } \\
\text { Islamic Certificate } \\
\text { (SBIS), inflation, } \\
\text { third party fund, } \\
\text { non-performing } \\
\text { financing, FDR, } \\
\text { ROA. }\end{array}$ & $\begin{array}{l}\text { Based on the result of this } \\
\text { research all the variables } \\
\text { observed can simultaneously } \\
\text { affect SMEs and non SMEs } \\
\text { conducted by sharia banks. } \\
\text { SME financing is influenced } \\
\text { by inflation, deposits, NPF } \\
\text { financing, FDR, and non } \\
\text { SMEs. As a result, sharia } \\
\text { banking should consider } \\
\text { these variables in conducting } \\
\text { SME financing. Non-SME } \\
\text { financing is influenced by } \\
\text { Inflation, DPK, FDR, and } \\
\text { SME financing. Thus, sharia } \\
\text { banking should consider } \\
\text { these variables in providing } \\
\text { financing for SMEs. }\end{array}$ \\
\hline
\end{tabular}




\begin{tabular}{|c|c|c|c|c|}
\hline No. & $\begin{array}{c}\text { Author and } \\
\text { Journal }\end{array}$ & Title & Variables & Results \\
\hline 8 & $\begin{array}{l}\text { Qi Zhang } \\
\text { Hong Liu. } \\
\text { Journal of } \\
\text { Chemical and } \\
\text { Pharmaceutical } \\
\text { Research, } \\
2014 \text {, } \\
6(5): 1818- \\
1824\end{array}$ & $\begin{array}{l}\text { Research on } \\
\text { small and medium } \\
\text { enterperises } \\
\text { financing mode } \\
\text { based on supply } \\
\text { chain finance. }\end{array}$ & $\begin{array}{l}\text { Supply chain } \\
\text { finance, financial } \\
\text { crisis, financing } \\
\text { on SME. }\end{array}$ & $\begin{array}{l}\text { Supply chain finance has } \\
\text { advantages in solving SME } \\
\text { financing difficulties. First, } \\
\text { it has more flexibility. with } \\
\text { the aid of supply chain } \\
\text { strength, upstream and } \\
\text { downstream enterprises } \\
\text { can use the flexibility of } \\
\text { financing strategy to obtain } \\
\text { various forms of financial } \\
\text { support. Second, it helps } \\
\text { direct financing where in } \\
\text { the mode of supply chain } \\
\text { financing, the core enterprise, } \\
\text { SME, financial institution } \\
\text { and the third party logistics } \\
\text { are a whole. Third, It is easy } \\
\text { to carry out folk financing } \\
\text { since supply chain provides } \\
\text { an information sharing } \\
\text { platform for bank and SME, } \\
\text { which effectively solves } \\
\text { the problem of information } \\
\text { asymmetry between banks } \\
\text { and enterprises. }\end{array}$ \\
\hline
\end{tabular}




\begin{tabular}{|c|c|c|c|c|}
\hline No. & $\begin{array}{c}\text { Author and } \\
\text { Journal }\end{array}$ & Title & Variables & Results \\
\hline 9 & $\begin{array}{l}\text { Nyankomo } \\
\text { Marwa. } \\
\text { International } \\
\text { Journal } \\
\text { of Trade, } \\
\text { Economics and } \\
\text { Finance, Vol. } \\
\text { 5, No. 3, June } \\
\text { (2014) }\end{array}$ & $\begin{array}{l}\text { Micro,Small } \\
\text { and Medium } \\
\text { Enterprises, } \\
\text { External } \\
\text { Financing } \\
\text { Challenges: } \\
\text { The Role of } \\
\text { Formal Financial } \\
\text { Institutions and } \\
\text { Development } \\
\text { Finance } \\
\text { Intervention in } \\
\text { Tanzania }\end{array}$ & $\begin{array}{l}\text { SME index, } \\
\text { financial } \\
\text { institutions, } \\
\text { financial } \\
\text { development. }\end{array}$ & $\begin{array}{l}\text { SME in Tanzania play a } \\
\text { significant role in income } \\
\text { generation, job creation and } \\
\text { poverty reduction. However, } \\
\text { the sector is facing significant } \\
\text { credit rationing from e formal } \\
\text { financial institutions. As a } \\
\text { result, the sector is highly } \\
\text { credit-constrained. The credit } \\
\text { rationing by formal financial } \\
\text { institutions is explained } \\
\text { mainly by the mismatch } \\
\text { between the requirements of } \\
\text { formal financial institutions' } \\
\text { lending process and structural } \\
\text { problems in SME's business } \\
\text { processes. The existing } \\
\text { mismatch leads to credit } \\
\text { market failure in the SME } \\
\text { market. }\end{array}$ \\
\hline 10 & $\begin{array}{l}\text { Gert Wehinger. } \\
\text { OECD Journal: } \\
\text { Financial } \\
\text { Market Trends } \\
\text { Volume } 2013 / 2 \\
\text { (2014) }\end{array}$ & $\begin{array}{l}\text { SMEs and the } \\
\text { credit crunch: } \\
\text { Current financing } \\
\text { difficulties, } \\
\text { policy measures } \\
\text { and review of } \\
\text { literature }\end{array}$ & $\begin{array}{l}\text { Foreign export, } \\
\text { SME, credit } \\
\text { crunch. }\end{array}$ & $\begin{array}{l}\text { Developments during the } \\
\text { crisis have shown that banks } \\
\text { significantly reduced their } \\
\text { foreign exposures and as } \\
\text { 'financial fragmentation' has } \\
\text { taken hold the countercyclical } \\
\text { effects of internal capital } \\
\text { markets has been working } \\
\text { less efficiently. }\end{array}$ \\
\hline
\end{tabular}

\section{DATA AND METHODOLOGY}

This study is quantitative research with descriptive approach. Descriptive statistics in research is basically a process of transforming research data in tabulation form so that it can be easily understood and interpreted. As it has been explained, the subject of this study is the fund channeled to SME by Islamic commercial banks. Thus, the data is also taken according to the topic of interest. The dependent data of the study is SME while the 
independent variables are the rate of return, third party funds and the rate of inflation. The type of data used in this study is secondary data obtained indirectly from third parties through intermediaries and various sources available which include, Bank Indonesia, SME Department and Islamic banking statistics of OJK.

This research will use multiple linear regression analysis tool which increases the number of free variable into two or more independent variables. In this study, multiple linear regression analysis is used to determine the relationship and influence level of internal factors towards SME financing in Islamic commercial banks. Before performing multiple regression analysis, this method requires to test classical assumption to get good result (Ghozali, 2006). The equation of regression is as per following:

$$
\mathrm{PKM}_{t}=\alpha+\beta_{1} \mathrm{DPK}_{t}+\beta_{2} \mathrm{INF}_{t}+\beta_{3} \mathrm{TM}_{t}+u_{t}
$$

Where :

PKM : SME financing (billion rupiah)

$\alpha \quad$ : Constant variable

$\beta \quad$ : Coefficient parameter

DPK : Third party fund (billion rupiah)

INF : Inflation (\%)

TM : Rate of return (\%)

$\mathrm{u} \quad$ : Error term

\section{RESULT AND DISCUSSION}

\section{Descriptive Analysis}

\section{Growth of Islamic Commercial Banks Financing on SME}

Financing is the provision of funding facilities to meet the needs of the parties of deficit unit which can be in the form of 
individual or legal body. Financing data for SME collected by OJK as compiled at Islamic Banking Statistics in 2012-2014 can be shown by the following graph:

Graph 1. Growth of Financing on SME 2012-2014

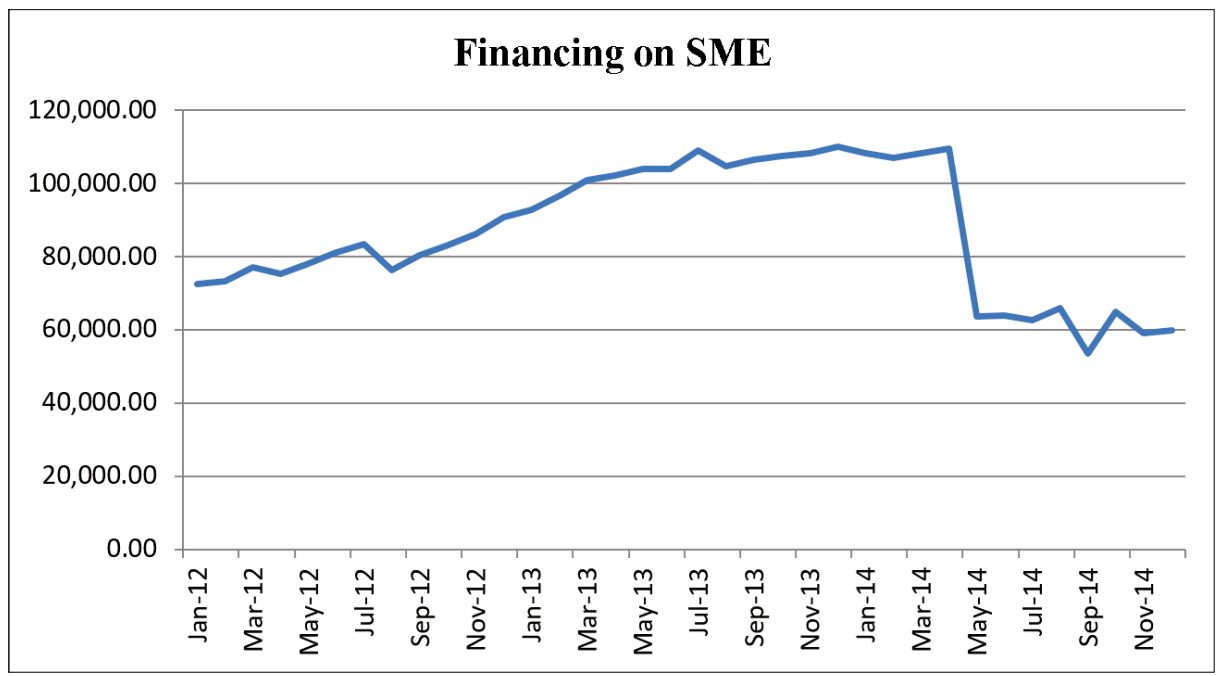

Source: Islamic Banking Statistics (processed data)

From the graph above, we can see that at the beginning of 2013 the financing reaches Rp. 92,672 billion up to July 2013 when it reaches Rp. 108,932 billion. Here, the financing for SME gains an increase. It then decreased slightly on August 2013 to Rp. 104,727 billion rupiahs before it increased again until the end of 2013 which amounts to Rp. 110,086 billion. Such increase did not last long since it dropped sharply until the end of 2014 when it touched merely $\mathrm{Rp} 60,000$ billion.

\section{The growth of third party fund}

Third party fund is the fund obtained by the bank from its customer which is the society. Islamic Banking Statistics had 
compiled the data for this third party fund. The following graph shows the third party fund statistics from 2012-2014.

Graph 2. Growth of Third Party Fund 2012-2014

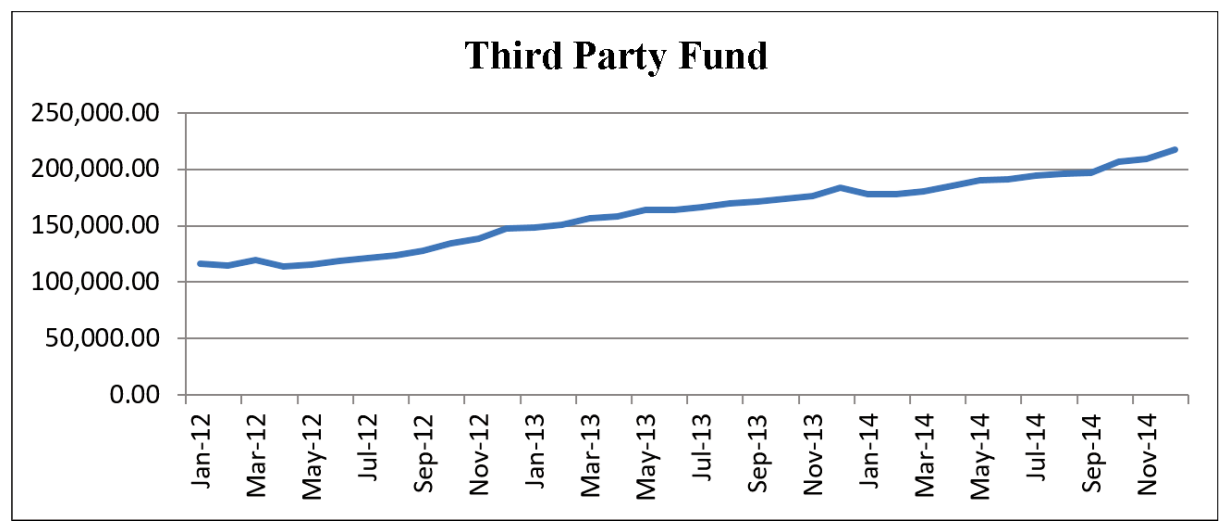

Source: Islamic Banking Statistics (processed data)

From the graphic above, we can see that Rp. 147,512 billion financing is recorded until the end of 2012. In the beginning of 2013 the total financing was Rp. 148,731 billion rupiah and keep increasing until the end of 2013. There was only slight decrease in the early 2014 which touched Rp. 177,930 billion, but then increased again in the next month until the end of year observed amounting to Rp. 217,858 billion rupiah. The decline in the development of third party funds is not evident in the graph above because the decrease is not significant.

\section{Inflation rate}

Inflation can be defined as the increase on prices. The data of inflation rate is shown on the graph 3. 
Graph 3. Inflation Rate 2012-2014

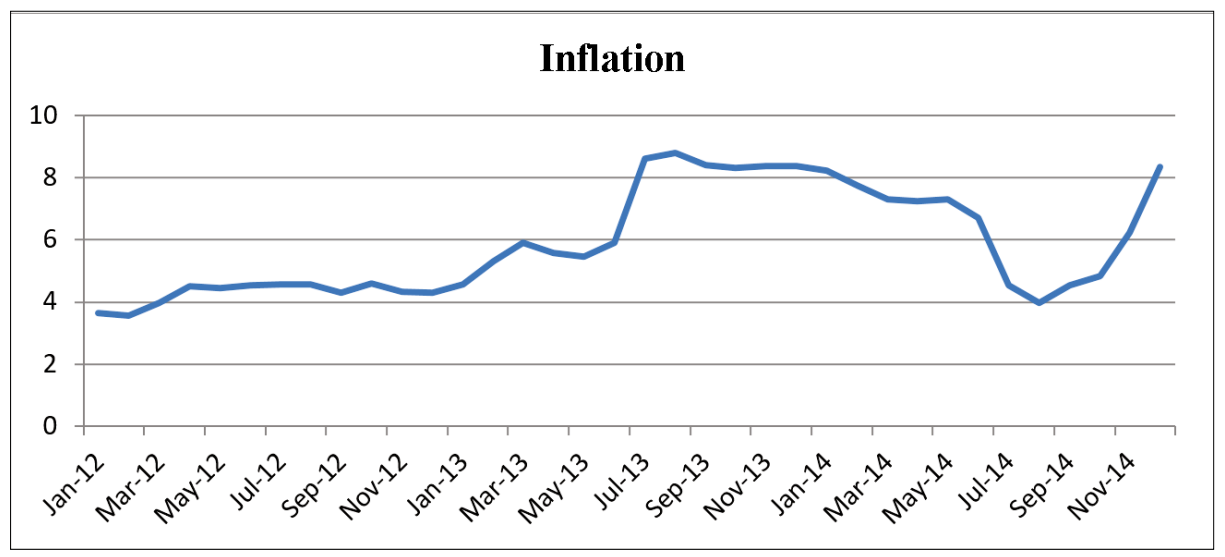

Source: Centre Body for Statistics

By observing the year end data from the graphic above, we can see that the lowest inflation rate happened at December 2012 that is $4.30 \%$. In December 2013, the inflation peaked into its higher level at $8.38 \%$. The inflation decreases only slightly in the end of 2014 by $0.02 \%$. From the above table, it is evident that the inflation in 2012 is generally lower compared to other years.

4. Rate of return

Islamic Banking Statistics also has compiled the data for the change of any rate of return through out the year. The graphic below will show the statistic. 
Graph 4. Rate of Return 2012-2014

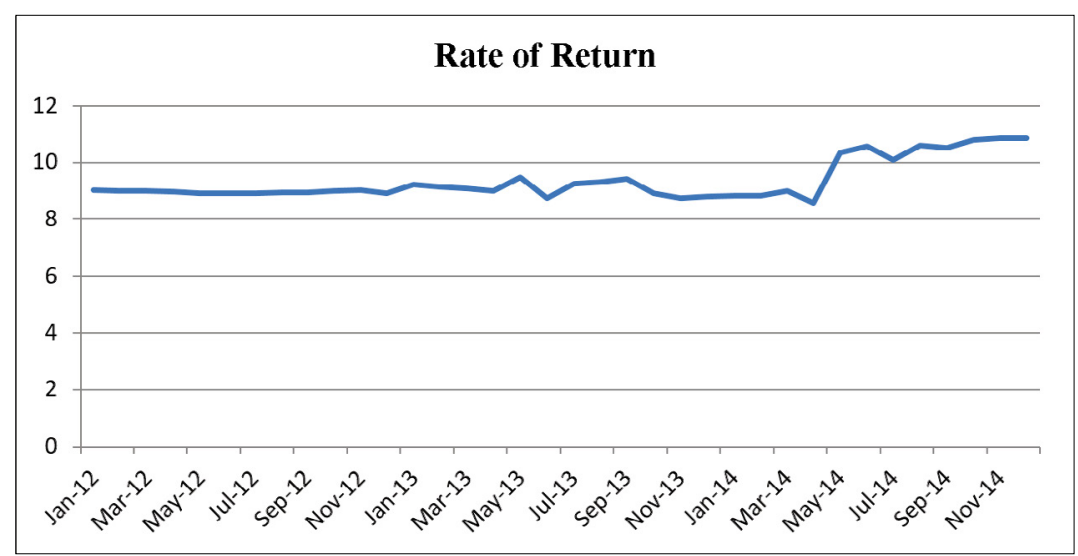

Source: Islamic Banking Statistics (processed data)

At the of 2012, the rate of return recorded at $8.92 \%$. Coming into January 2013 , it increased by $0.3 \%$ into $9.22 \%$ while it decreased into $8.79 \%$ at the end of the same year. However, it recorded the highest increase at the end of 2014 which was $10.86 \%$. The rate of return actually fluctuates in each of the months. However, it seems not to be evident in the graphic since the increase or decrease is insignificant.

\section{Estimation Result}

\section{Statistical interpretation}

As it has mentioned above, we use multiple linear regression in order to know the relation between the variables. The result of the regression is as per following. 
Table 3. Regression Result

$$
\begin{gathered}
P K M_{t}=269081.2+0.251143 D P K_{t}+3146.138 I N F_{t}-25783.53 T M_{t} \\
(0.0067)^{*}(0.0104)^{* *}(0.0000)^{*} \\
\mathrm{R}^{2}=0.844232 ; \mathrm{DW}-\mathrm{Stat}=1.307656 ; \mathrm{F}-\mathrm{Stat}=57.81141 ; \text { Sig.F-Stat }=0.000000
\end{gathered}
$$

Diagnosis testing

1. Multicollinearity (VIF test)

$$
D P K=4.434988 I N F=2.478560 \quad T M=2.963089
$$

2. Autocorrelation (Breusch Godfrey test)

$$
x^{2}(3)=0.614252 \operatorname{sig}\left(x^{2}\right)=0.8932
$$

3. Linearity (Ramsey Reset test)

$$
\mathrm{F}(2,28)=1.245321 \operatorname{sig}(\mathrm{F})=0.3033
$$

4. Normality (Jarque Bera test)

$$
x^{2}=4.338550 \operatorname{sig}\left(x^{2}\right)=0.114260
$$

5. Heteroscadasticity (White test)

$$
x^{2}(9)=12.03249 \operatorname{sig}\left(x^{2}\right)=0.2115
$$

Keterangan : *Signifikan pada $\alpha=0.01 ; * *$ Signifikan pada $\alpha=0.05$; $* * *$ Signifikan pada $\alpha=0.10$; Angka dalam kurung adalaah probabilitas nilai t-statistik.

Before explaining the result, we would like to first discuss the diagnosis testing. This is because when regression falls to fulfill the entire classical assumptions, the regression result could be bias or inefficient. First, we find no multicollinearity after conducting VIF test since none of the value exceeds the limit which is 10. The Breush Godfrey test for the autocorrelation also shows that our regression does not encounter problem of autocorrelation since the $\operatorname{sig}\left(x^{2}\right)=0.8932$. We also test for the model specification using Ramsey Reset test. The result shows that our model is well specified since the $\operatorname{sig}(\mathrm{F})=0.3033$. For the normality, we conduct the Jarque Bera test which shows that $\operatorname{sig}\left(x^{2}\right)=0.114260$ meaning our model has normal distribution function. Lastly, the White test for heteroscadasticity shows 
that the regression does not suffer from any heteroscadasticity problem as the value $\operatorname{sig}\left(x^{2}\right)=0.2115$

We also conducted the model examination to know whether the variables as a whole are significant or not by using F-test. Here, the F-stat probability has the value of 0.000000 which means the model is significant or in other word it does exist. Apart from the F-test, we also interested in the result of $\mathrm{R}^{2}$. The $\mathrm{R}^{2}$ value which is 0.844232 shows that almost $85 \%$ of the change in the dependent variable (PKM) can be explained by three independent variables we investigate here. Meanwhile, the rest variation is explained by variables outside the model.

Since we are done with all the tests, we can now proceed to the estimation interpretation part. The third party fund affects significantly and positively on the SME financing. The coefficient shows the value of 0.251143 which means any one billion rupiah increase in third party fund would be associated with the increase of SME financing by 0.251143 billion rupiah while one billion rupiah decrease in third party fund would by associated with the decrease of SME financing by 0.251143 billion rupiah assuming the other variables hold constant.

In the same time, inflation is also has significant and positive impact on the SME financing. Since the coefficient is 3146.138 , it means that an increase in inflation by $1 \%$ will affect SME financing to increase by 3146.138 billion rupiah while the decrease of inflation impacts the same amount of decrease on SME financing assuming the other variables hold constant. The rate of return is also significant with negative sign with the value -25783.53 . Thus, $1 \%$ increase on rate of return will makes the SME financing decrease by 25783.53 billion rupiah, and the opposite is true assuming the other variables hold constant. 


\section{Economic interpretation}

First, the significant and positive effect of third party fund on the SME financing means that more third party fund is needed. Thus, bank must attract more people to save their money under their custody so that the amount for financing channeled to the SME could increase. Even though the third party fund is not necessarily meant to be channeled to SME, it at least adds the possibility of such financing. The results of this study conforms what has been done by Nurhidayah and Any Isvandiari (2016) with their publication titled "Internal Factors and External Factors Affecting Allocation of Small and Medium Business Financing (Study on Indonesia Islamic Banks)". The results showed that third party fund affects SME financing.

Second, inflation has a positive and significant effect on the financing of SME. This means that the relationship between Inflation towards financing of SME is very influential. The increasing rate of inflation in Indonesia will lead to an increase in the amount of funds channeled for the financing of SME. The result here also conform previous study which is done by Sri Delasmi and Deky Anwar (2016) entitled “The Effect of Inflation, BI Rate on Micro and Small Business Financing (Case Study at Sharia Commercial Bank)" that there is a significant influence between the independent variable of inflation on the dependent variable of UMKM financing.

The last variable which is rate of return shows significant effect yet with the negative sign. This means that the increase and decrease in financing of small and medium enterprises is strongly influenced by the rate of return of Islamic Commercial Bank. 
This is because from the rate of return determination, the Bank will get advantage when doing financing to customers. However, the result of this study is in the contrast with the research of Nurhidayah and Any Isvandiari (2016). The $t$ test on margin level variables shows that $t$ value has negative and insignificant value to the allocation of SME financing of Indonesian sharia bank, this indicates that the increase and decrease in the level of financing margin does not affect the allocation of financing to SME.

\section{CONCLUSION AND SUGGESTION}

The regression model in this study has past all the tests to fulfill the classical assumptions on regression. The test includes normality, multicollinearity, autocorrelation, heteroscadasticity and model specification. According to t-test, all variables in the study are significant with both positive and negative signs and various magnitudes. The third party fund affects significantly with positive sign and having the coefficient of 0.251143 . In the same time, inflation impacts significantly and positively towards SME financing with the magnitude 3146.138. At the last, rate of return is significant but having negative sign with the coefficient -25783.53. However, we acknowledge that the study here has limitation in which we only observe from year 2012 until 2014.

Based on these results, some suggestions can be proposed. First of all, it is important for the government to maintain monetary stability to boost up SME financing. This monetary stability which includes inflation has the effect on SME financing as we have seen above. Secondly, Islamic commercial banks should pay more attention on their rate of return because all SME players do take into consideration the rate of return the bank would offer 
based on the result of this paper.

\section{REFERENCE}

Arieffandi, R. Y., Firdaus, M., \& Sasongko, H. (2016). Faktorfaktor Yang Mempengaruhi Tingkat Kolektibilitas Pembiayaan Sektor UMKM (Studi Kasus: Bank Syariah XYZ Kantor Cabang Jakarta Barat). Jurnal Aplikasi Bisnis dan Manajemen, Vol. 2 No 3.

Astarini, R. P., Hartoyo, S., \& Maulana, T. N. (2015). The Impact of Internal and External Factors on Financing of Sharia Banks in Indonesia. International Journal of Science and Research, Volume 5 Issue 9.

Aziz, R. M. (2017). Development Of Small Medium Entreprise With External, Internal, And Religiosty Factors In Islamic Banks. KINERJA, 17-34.

Data Inflasi. (2012). Diambil kembali dari Bank Sentral Republik Indonesia: http://www.bi.go.id/id/moneter/inflasi/data

Data Inflasi. (2013). Diambil kembali dari Bank Sentral Republik Indonesia: http://www.bi.go.id/id/moneter/inflasi/data

Data Inflasi . (2014). Diambil kembali dari Bank Sentral Republik Indonesia: http://www.bi.go.id/id/moneter/inflasi/data

Ghozali, I. (2006). Aplikasi Analisis Multivariate Dengan Program SPSS. Semarang: Badan Penerbit Universitas Diponegoro.

Irawan, O., Khalil, J., \& Amin, A. R. (2016). Dana Pihak Ketiga, Rasio Kecukupan Modal, Pembiayaan Bermasalah, dan Tingkat Pengembalian Investasi Pada Pembiayaan UMKM. Jurnal Liquidity, 127-133. 
Jayanti, S. D., \& Anwar, D. (2016). Pengaruh Inflasi dan BI Rate Terhadap Pembiayaan Usaha Mikro Kecil dan Menengah (Studi Pada Bank Umum Syariah). I-Economic, vol.2, no 2.

Kara, M. (2013). Konstribusi Pembiayaan Perbankan Syariah Terhadap Pengembangan Usaha Mikro, Kecil dan Menengah. Ahkam, Vol XIII, No 2.

Marwa, N. (2014). Micro, Small and Medium Enterprises' External Financing Challenges : The Role of Formal Financial Institusi and Development Finance Intervention in Tanzania. International Journal of Trade Economic and Finance, Vol 5 No 3.

Nurhidayah, \& Isvandiari, A. (2016). Faktor Internal dan Eksternal Yang Mempengaruhi Alokasi Pembiayaan Usaha Kecil Menengah (Studi Pada Bank Syari'ah Indonesia). Jurnal JIBEKA, 42-48.

Prawirokusumo, S. (2001). Ekonomi Rakyat : Konsep, Kebijakan, dan Strategi . Yogyakarta: BPFE.

Qi Zhang, H. L., \& QI, X. (2014). Research on Small and Medium Enterprise Financing Mode Based on Supply Chain Finance. Journal of Chemical and Pharmaceutical Research, 6(5) : 1818-1824.

Statistika Perbakan Syariah. (2012). Diambil kembali dari Otoritas Jasa Keuangan:http://www.ojk.go.id/id/kanal/ syariah/data-dan-statistik/statistik-perbankan-syariah/ default.aspx

Statistika Perbankan Syariah. (2013). Diambil kembali dari Otoritas Jasa Keuangan:http://www.ojk.go.id/id/kanal/ syariah/data-dan-statistik/statistik-perbankan-syariah/ 
default.aspx

Statistika Perbakan Syariah. (2014). Diambil kembali dari Otoritas Jasa Keuangan:http://www.ojk.go.id/id/kanal/ syariah/data-dan-statistik/statistik-perbankan-syariah/ default.aspx

Wehinger, G. (2014). SMEs and the credit crunch : Current Financing difficulties, policy measures and a review of literature. Journal : Financial Market Trends, VOL 2.

Winarni, S. (2006). Strategi Pengembangan Usaha Kecil Melalui Peningkatan Aksesibilitas Kredit Perbankan. Infokop Nomor 29 Tahun XXII. 